\title{
Chemical composition, antimicrobial and antifungal activities of essential oils of the leaves of A eglemarmelos (L.) Correa growing in Egypt
}

\author{
Nabaweya A. Ibrahim ${ }^{1}$, Fatma S. El-Sakhawy ${ }^{2}$, Magdy M. D. Mohammed ${ }^{1, *}$, Mohamed A. Farid ${ }^{3}$, Nayera A.M. Abdel- \\ Wahed $^{3}$, Doaa A.H. Deabes ${ }^{1}$ \\ ${ }^{1}$ Pharmacognosy Department, Pharmaceutical and Drug Industries Research Division, National Research Center, Dokki-12311, Cairo, Egypt. \\ ${ }^{2}$ Pharmacognosy Department, Faculty of Pharmacy, Cairo University, Giza, Egypt. \\ ${ }^{3}$ Chemistry of Natural and Microbial Products Department, Pharmaceutical and Drug Industries Research Division, National Research Center, Dokki- \\ 12311, Cairo, Egypt.
}

\author{
ARTICLE INFO \\ Article history: \\ Received on: 31/10/2014 \\ Revised on: 27/11/2014 \\ Accepted on: 09/01/2015 \\ Available online: $27 / 02 / 2015$ \\ Key words: \\ Aegle marmelos (L.) Correa, \\ essentialoil,antimicrobial and \\ antifungal activities, spore \\ germenation.
}

\begin{abstract}
The essential oil obtained by hydro-distillation of Aegle marmelos (L.) Correa leaves were analyzed by GC/MS yield $(0.9 \% \mathrm{v} / \mathrm{w})$. Twenty seven components were identified representing $97.76 \%$ of the total oil composition. The major components were $\alpha$-phellenderene $(20.97 \%), \alpha$-pinene $(17.76 \%)$ and $\delta$-carene $(16.37 \%)$ and other abundant components as $\gamma$-cadinene $(8.01 \%)$, trans-2-hydroxycinnmic acid $(6.85 \%)$ and $\beta$-myrcene $(4.32 \%)$. The essential oil exhibited significant antibacterial activity against Gram-positive bacteria as Streptococcus faecalis with inhibition zone $(30 \mathrm{~mm})$ and Gram-negative bacteria as Pseudomonas aeruginosa $(28 \mathrm{~mm})$. Moreover, moderate activity was observed against Bacillus subtilis $(23 \mathrm{~mm})$, Staphylococcus aureus $(23 \mathrm{~mm})$, Sarcina lutea $(20 \mathrm{~mm})$, Arthrobacter citreus $(20 \mathrm{~mm})$ and Escherichia coli $(25 \mathrm{~mm})$ in comparison with antibiotics. The antifungal activity against Aspergillus niger $(30 \mathrm{~mm})$ and Candida albicans $(30 \mathrm{~mm})$ was higher than the antifungal antibiotics. Moreover, the oil inhibited the germination of Aspergillus niger and Fusarium oxysporum spores at different concentrations.
\end{abstract}

\section{INTRODUCTION}

Aegle marmelos (L.) Correa is a tree belongs to family Rutaceae commonly known as bael; it is native to Northern India but widely found throughout Indian Peninsula and in a Ceylon, Burma, Bangladesh, Thailand and Indo-China(Rahman and Parvin, 2014).It is traditionally used for treatment of various diseases such as dysentery, fever, diabetes, asthma, heart problems, ophthalmia, haemorrhoids and urinary problems (Bansal and Bansal 2011).Moreover,thealcoholic leaves extract used as anti-ulcer (Shenoy et al., 2012), anti-diabetic (Bhatti et al., 2012),antibacterial and antifungal activities (Venkatesan et al., 2009, Kothari et al., 2011).

\footnotetext{
* Corresponding Author

Magdy M. D. Mohammed, Pharmacognosy Department, Pharmaceutical and Drug Industries Research Division, National Research Center, Dokki-12311, Cairo, Egypt. Email: melhenawy111@gmail.com
}

In addition it has antiproliferative and antioxidant activities (Chockalingam et al., 2012). The leaf extracts significantly inhibits the dermatophytic fungilike Trichophyton mentagrophytes, T. rubrum, Microsporum canis, M.gypseum and Epidermophyton floccosum (Balakumar et al., 2011). Various phytochemical constituents have been isolated from the different extracts of the leaves i.e., alkaloids, cardiac glycosides, terpenoids, saponins, tannins, flavonoids and steroids (Sekar et al., 2011), in addition to coumarins, polysaccharides, seed oil and carotenoids from different parts of the tree(Dhankhar et al., 2011). The antifungal activity of essential oil isolated from leaves was evaluated using spore germination assay. The oil exhibited variable efficacy against different fungi and the inhibition of spore germination was $100 \%$ at $500 \mu \mathrm{g} / \mathrm{mL}$ (Rana et al., 1997). The insecticidal, larvicidal and nematocidal activities of the oil isolated from A. marmelos leaves of Nepal sources due to the presence of high level of limonene $(64.1 \%)$ (Satyal et al., 2012). 
Furthermore, the oil isolated from $A$. marmelos leaves of Cuba sources contains $\delta$-cadinene $(12.1 \%)$ and $\beta$-caryophyllene (10\%)as major compounds (Pinoet al., 2005).On the other hand, the oil isolated from $A$. marmelosleaves growing in India composed mainly of $\alpha$-phellandrene (39.2\%) and limonene (26.8\%) (Raju et al., 1999). The aims of the present study were to isolate the essential oil of the leaves of Aegle marmelos (L.)Correa growing in Egypt in order to identify its constituents and to evaluate its antibacterial and antifungal activities.

\section{MATERIALS AND METHODS}

\section{Plant materials}

Fresh leaves of Aegle marmelos (L.) Correa were collected from El-Zohrya Garden, Giza, Egypt during flowering stage in April 2008. The plant materials were identified by Mrs. Therese Labib, consultant of taxonomy at the ministry of agriculture and the former director of El-Orman Botanical Garden, Giza, Egypt. A voucher specimen (No.00017 1Ac 04-02-05-17) of the plant was kept at the Herbarium of El-Orman Botanical Garden.

\section{Essential oil isolation}

Fresh leaves of A. marmelos (L.)Correa(300 g)were subjected to hydrodistillation method using Clevenger apparatus (Egyptian Pharmacopoeia, 2005), which was repeated three times and then the mean percentage of each yield was calculated. The obtained oil was dried over anhydrous sodium sulphate and stored at $-20^{\circ} \mathrm{C}$. The essential oil was diluted (1:10 hexane, v/v), $0.2 \mu \mathrm{L}$ of the oil was analyzed by GC-MS using the following conditions.

\section{Analysis of the essential oil}

The oil was analyzed by trace GC ultra-Gas Chromatographs (THERMO Scientific Corp., USA), coupled with a THERMO mass spectrometer detector (ISQ Single Quadrupole Mass spectrometer). The capillary column of fused silica $(30 \mathrm{~m} \mathrm{x}$ $0.25 \mathrm{~mm}$ ID $\mathrm{x} 0.25 \mu \mathrm{m}$ (film thickness) was used. Analyses were carried out using helium as carrier gas at a flow rate of $1.0 \mathrm{~mL} / \mathrm{min}$ at a split ratio of $1: 10$ and the following temperature program:50 ${ }^{\circ} \mathrm{C}$ for $1 \mathrm{~min}$; rising at $5.0^{\circ} \mathrm{C} / \mathrm{min}$ to $180^{\circ} \mathrm{C}$ and held for $6 \mathrm{~min}$; rising at $5^{\circ} \mathrm{C} / \mathrm{min}$ to $250^{\circ} \mathrm{C}$ and held for $1 \mathrm{~min}$ the injector and detector were held at $250^{\circ} \mathrm{C}$ and $240^{\circ} \mathrm{C}$, respectively. Mass spectra were obtained by electron ionization (EI) at $70 \mathrm{eV}$ using a spectral range of $40-450 \mathrm{~m} / \mathrm{z}$. The identification of the components was based on comparison of their mass spectral fragmentations pattern with those of the data reported in Wiley and NISTLibraries and those described by (Adams, 2001).

\section{Microorganisms}

The bacteria used in this study were Gram-positive bacterial strains i.e., Bacillus subtilis NRRL 543, Staphylococcus aureus NRRL B-313,Sarcina lutae NRRL B-1018,Streptococcus faecalis NRRL 537and Arthrobacter citreus NRRL B-1258,Gramnegative bacterial strains i.e., Escherichia coli NRRL B-210,
Klebsiella pneumonia NRRL B-117and Pseudomonas aeruginosa NRRL B-23. Fungi i.e., Aspergillus niger NRRL 599, Fusarium oxysporum NRRL 28184 and Candida albicans NRRL Y-477. These micro-organisms obtained from Northern Utilization Research and Development Division, United State Department of Agriculture, Peoria, Illinois, USA. The bacterial strains were revived for bioassay by sub-culturing in fresh nutrient broth medium for 24 hours before test. While fungi were cultured on potato dextrose agar (PDA) $\left(2.5 \% \mathrm{w} / \mathrm{v}\right.$ agar) for 7 days at $28^{\circ} \mathrm{C}$ before the experiment was carried out.

\section{Agar diffusion method}

The antibacterial and antifungal activities of the essential oil were tested using agar diffusion method (Linday, 1962).0.1 mL suspension of 24 hours bacterial cultures in sterile distilled water was added to $40 \mathrm{~mL}$ sterile nutrient agar media. For fungal strains, $0.1 \mathrm{~mL}$ suspension of seven days cultures was added to $40 \mathrm{~mL}$ sterile PDA (potato dextrose agar) at $45^{\circ} \mathrm{C}$. The mixture was transferred to sterile Petri dishes and allowed to solidify. Holes of $9 \mathrm{~mm}$ in diameter were made using a cork borer. Amounts of $0.1 \mathrm{~mL}$ of the diluted essential oil with paraffin oil were poured inside the holes. A hole filled with paraffin oil only was also used as control.

The plates were left for 1 hour at room temperature as a period of pre-incubation diffusion. The diameters of the inhibition zone were measured and compared with that of the standard and the values were tabulated. Plate cultures were kept in an incubator at $28^{\circ} \mathrm{C}$ for 48 hours for fungi and at $37^{\circ} \mathrm{C}$ for 24 hours for bacteria.

Erythromycin, methicillin, oxacillin, bacitracin and nystatin were included during the experiment as references antibiotics. Following incubation, the zone of inhibition for each sample was recorded in $\mathrm{mm}$ (including the hole). Microorganisms with zone size $\geq 28 \mathrm{~mm}$ were classified as strongly sensitive, with a zone diameter of $<28$ to $16 \mathrm{~mm}$ as moderately sensitive, with a zone diameter of < 16 to $12 \mathrm{~mm}$ as weakly sensitive and isolates with zone diameter of $<12 \mathrm{~mm}$ as resistant (Elgayyar et al., 2001). Plates were done in triplicate and an average + SD was recorded (Table 2).

\section{Estimation of Minimal Inhibitory Concentration}

The minimal inhibitory concentration (MIC) of the oil was determined by broth dilution method previously established by (Carson et al., 1995) in test tubes containing 5mLnutrient broth. Serial two fold dilutions of stock solution of essential oil were prepared over the range of $1.0-200 \mu \mathrm{L} / \mathrm{mL}$. A $50 \mu \mathrm{L}$ spore suspension of each test strain was inoculated in the test tubes and incubated for $24-72$ hours at $37^{\circ} \mathrm{C}$. The control tube containing the same medium was inoculated only with microorganism's suspension without essential oil. The minimum inhibitory concentrations at which no visible growth observed (100\% inhibition) were defined as the MICs which were expressed in $\mu \mathrm{L} / \mathrm{mL}$ (Table 3 ) all dilutions were performed in duplicate. 


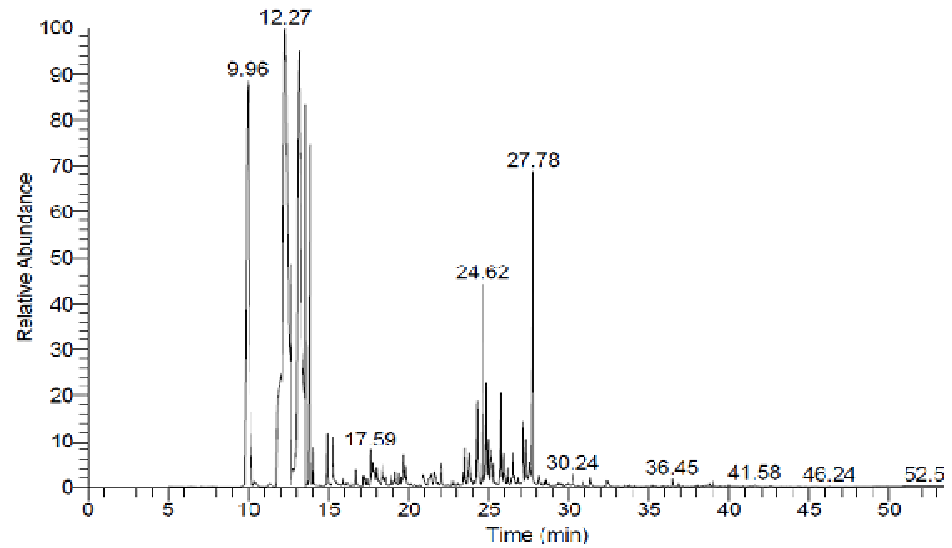

Fig. 1:Gas ion chromatogram of the essential oil of Aegle marmelos (L.) Correa leaves.

Table 1: Chemical compositions of the essential oil of A. marmelos (L.) Correa leaves.

\begin{tabular}{|c|c|c|c|c|c|c|c|}
\hline Peak No. & Compound & MF & Area \% & $\mathrm{M}^{+}$ & Main Fragments & $\mathbf{R}_{\mathrm{t}}$ & $\mathbf{R R}_{\mathbf{t}}$ \\
\hline 1 & $\alpha$-Pinene & $\mathrm{C}_{10} \mathrm{H}_{16}$ & 17.76 & 136 & $93(100), 79,121$ & 9.96 & 0.8 \\
\hline 2 & $\beta$-Myrcene & $\mathrm{C}_{10} \mathrm{H}_{16}$ & 4.32 & 136 & $41,93,69,81$ & 11.84 & 0.9 \\
\hline 3 & $\alpha$-Phellandrene & $\mathrm{C}_{10} \mathrm{H}_{16}$ & 20.97 & 136 & $93,91,77,105$ & 12.27 & 1 \\
\hline 4 & Isosylvestrene & $\mathrm{C}_{10} \mathrm{H}_{16}$ & 1.70 & 136 & $93,67,121,136$ & 12.37 & 1.01 \\
\hline 5 & $\delta$-Carene & $\mathrm{C}_{10} \mathrm{H}_{16}$ & 16.37 & 136 & $93,79,105,121$ & 13.13 & 1.07 \\
\hline 6 & $\beta$-Ocimene & $\mathrm{C}_{10} \mathrm{H}_{16}$ & 2.51 & 136 & $93,79,105$ & 13.55 & 1.1 \\
\hline 7 & trans-2-hydroxycinnmic acid & $\mathrm{C}_{9} \mathrm{H}_{8} \mathrm{O}_{3}$ & 6.85 & 164 & $91,77,65,103$ & 13.79 & 1.12 \\
\hline 8 & $\gamma$-Terpinene & $\mathrm{C}_{10} \mathrm{H}_{16}$ & 0.66 & 136 & $93,91,77,41$ & 14.05 & 1.14 \\
\hline 9 & Terpenolene & $\mathrm{C}_{10} \mathrm{H}_{16}$ & 1.02 & 136 & $93,121,79,41$ & 14.90 & 1.2 \\
\hline 10 & Linalool & $\mathrm{C}_{10} \mathrm{H}_{22} \mathrm{O}$ & 1.08 & 154 & $43,71,93,55$ & 15.26 & 1.24 \\
\hline 11 & 3-Isothujanol & $\mathrm{C}_{10} \mathrm{H}_{18} \mathrm{O}$ & 0.45 & 154 & $43,55,67,81$ & 16.69 & 1.36 \\
\hline 12 & 4-Terpineol & $\mathrm{C}_{10} \mathrm{H}_{18} \mathrm{O}$ & 0.79 & 154 & $71,93,55$ & 17.59 & 1.4 \\
\hline 13 & Thuj-3-en-10-al & $\mathrm{C}_{10} \mathrm{H}_{14} \mathrm{O}$ & 0.75 & 150 & $79,51,91,107$ & 17.78 & 1.45 \\
\hline 14 & $\alpha$-Terpineol & $\mathrm{C}_{10} \mathrm{H}_{18} \mathrm{O}$ & 0.45 & 154 & $59,43,81,93$ & 17.99 & 1.46 \\
\hline 15 & Unknown & & 0.67 & & $126,108,69,55$ & 21.34 & 1.7 \\
\hline 16 & Unknown & & 0.55 & & $111,71,81,126$ & 21.62 & 1.76 \\
\hline 17 & $\delta$-Elemene & $\mathrm{C}_{15} \mathrm{H}_{24}$ & 0.80 & 204 & $93,121,41,79$ & 23.52 & 1.9 \\
\hline 18 & $\alpha$-Cubebene & $\mathrm{C}_{15} \mathrm{H}_{24}$ & 1.70 & 204 & $105,119,41,161$ & 24.28 & 1.98 \\
\hline 19 & $\gamma$-Elemene & $\mathrm{C}_{15} \mathrm{H}_{24}$ & 3.82 & 204 & $121,93,41,67$ & 24.62 & 2 \\
\hline 20 & $\alpha$-Humulene & $\mathrm{C}_{15} \mathrm{H}_{24}$ & 0.97 & 204 & $93,67,79,41$ & 24.96 & 2.03 \\
\hline 21 & Unknown & & 1.02 & & $93,79,67$ & 25.15 & 2.05 \\
\hline 22 & $\alpha$-Terpinyl isobutyrate & $\mathrm{C}_{14} \mathrm{H}_{24} \mathrm{O}_{2}$ & 0.61 & 224 & $43,81,9,121$ & 25.30 & 2.06 \\
\hline 23 & $\gamma$-Muurolene & $\mathrm{C}_{15} \mathrm{H}_{24}$ & 1.62 & 204 & $161,105,41,119$ & 25.72 & 2.09 \\
\hline 24 & $\gamma$-Curcumene & $\mathrm{C}_{15} \mathrm{H}_{24}$ & 0.77 & 204 & $119,41,93,105$ & 25.82 & 2.1 \\
\hline 25 & Valencene & $\mathrm{C}_{15} \mathrm{H}_{24}$ & 0.68 & 204 & $161,105,91,119$ & 25.97 & 2.11 \\
\hline 26 & $\beta$-Selinene & $\mathrm{C}_{15} \mathrm{H}_{24}$ & 0.45 & 204 & $93,79,67,41$ & 26.18 & 2.16 \\
\hline 27 & $\alpha$-Muurolene & $\mathrm{C}_{15} \mathrm{H}_{24}$ & 1.32 & 204 & $105,41,161,93$ & 27.31 & 2.21 \\
\hline 28 & $\beta$-Bisabolene & $\mathrm{C}_{15} \mathrm{H}_{24}$ & 0.89 & 204 & $41,69,93,79$ & 27.53 & 2.22 \\
\hline 29 & $\gamma$-Cadinene & $\mathrm{C}_{15} \mathrm{H}_{24}$ & 8.01 & 204 & $161,105,91,119$ & 27.78 & 2.26 \\
\hline 30 & $\beta$-Bisabolol & $\mathrm{C}_{15} \mathrm{H}_{26} \mathrm{O}$ & 0.43 & 222 & $41,67,93,82$ & 30.24 & 2.4 \\
\hline
\end{tabular}

MF: Molecular formula

$\mathrm{R}_{\mathrm{t}}$ : Retention time

$\mathrm{RR}_{\mathrm{t}}$ : Relative Retention Time to $\alpha$-phellandrene (12.26).

Table 2: Antimicrobial activities of the essential oil from A. marmelos(L.)Correa.

\begin{tabular}{|c|c|c|c|c|c|c|}
\hline \multirow[b]{2}{*}{ Test organism } & \multicolumn{6}{|c|}{ Inhibition zone diameter(mm) } \\
\hline & $\begin{array}{c}\text { Essential oil } \\
(1: 50 \mathrm{v} / \mathrm{v})\end{array}$ & Erythromycin $150 \mu \mathrm{g} / \mathrm{mL}$ & $\begin{array}{c}\text { Methicillin } \\
50 \mu \mathrm{g} / \mathrm{mL}\end{array}$ & $\begin{array}{l}\text { Oxacilin } \\
10 \mu \mathrm{g} / \mathrm{mL}\end{array}$ & Bacitracin $100 \mu \mathrm{g} / \mathrm{mL}$ & $\begin{array}{c}\text { Nystatin } \\
100 \mu \mathrm{g} / \mathrm{mL}\end{array}$ \\
\hline \multicolumn{7}{|l|}{ Gram positive } \\
\hline B. subtilis & 23 & 26 & 14 & $-v e$ & 18 & 11 \\
\hline S. aureus & 23 & 16 & $-\mathrm{ve}$ & $-\mathrm{ve}$ & 12 & 12 \\
\hline S.lutea & 20 & 25 & 24 & 24 & 26 & -ve \\
\hline S. faecalis & 30 & 20 & $-\mathrm{ve}$ & $-\mathrm{ve}$ & 19 & $-\mathrm{ve}$ \\
\hline A. citreus & 20 & 28 & 19 & 24 & 12 & 12 \\
\hline \multicolumn{7}{|l|}{ Gram negative } \\
\hline E. coli & 25 & 16 & 11 & 12 & 12 & $-v e$ \\
\hline K. pneumoniae & $-v e$ & $-\mathrm{ve}$ & 12 & 14 & $-v e$ & $-\mathrm{ve}$ \\
\hline P. aeruginosa & 28 & 35 & 17 & 15 & 12 & $-\mathrm{ve}$ \\
\hline \multicolumn{7}{|l|}{ Fungi } \\
\hline A. niger & 30 & $-v e$ & $-v e$ & $-v e$ & $-v e$ & 15 \\
\hline C. albicans & 30 & $-v e$ & $-v e$ & $-\mathrm{ve}$ & $-v e$ & 15 \\
\hline
\end{tabular}




\section{Spore germination assay}

Spore germination assay was carried out according to (Rana et al., 1997). Three concentrations of the essential oil (4, 2, $1 \% \mathrm{v} / \mathrm{v}$ ) and controls (one sterile distilled water and other $0.1 \%$ $(\mathrm{v} / \mathrm{v})$ methanol in sterile distilled water) were tested for spore germination of Aspergillus niger and Fusarium oxysporum. Aliquots of $0.1 \mathrm{~mL}$ from each sample were mixed with fungal spores obtained from 10 days cultures of the fungi and placed on separate glass slides in triplicate. Slides containing the spores were incubated in a moist chamber at $28^{\circ} \mathrm{C}$ for 24 hours. Each slide was then fixed in lactophenol-cotton blue and observed under the microscope for spore germination (Table 4)a spore was considered germinated when the germ tube length was 1.5 times the spore diameter (Plascencia-Jatomea et al., 2003).

\section{RESULTS AND DISCUSSION}

The percentage of the volatile oil from fresh leaves of $A$. marmelos (L.) Correa was 0.9\% (v/w). GC/MS analysis of oil revealed the presence of 30 components as shown (Table $1 \&$ Figure 1), from which 27 compounds were identified represent $(97.76 \%)$ of the total oil composition, classified into; monoterpene hydrocarbon represented the most abundant constituents of the oil $(65.31 \%)$ i.e., $\alpha$-phellandrene $(20.97 \%), \alpha$-pinene $(17.76 \%)$ and $\delta$ carene $(16.37 \%)$ were major components identified, and sesquiterpenes hydrocarbons represented (21.03\%) i.e., $\gamma$-cadinene $(8.01 \%)$ was the major component, oxygenated compounds representing (11.41\%) i.e., monoterpens alcohols (2.77\%), sesquiterpene alcohols $(0.43 \%)$, aldehyde $(0.75 \%)$, ester $(0.61 \%)$ and trans-2-hydroxycinnmic acid $(6.85 \%)$ reported here for the first time from A. marmelos (L.) Correa. Previous report by (Raju et al., 1999) confirmed the high content of monoterpenes in the leaves oil which agreed with our results. However, the concentration of $\alpha$-phellandrene (39.2\%), $\alpha$-pinene (6.6\%) were quite different that our study, in which the percentages of $\alpha$ phellandrene and $\alpha$-pinene were (20.97\%) and(17.76\%) respectively.

On the other hand, our obtained results were different from the leaves oil isolated from Cuba sources, which constituted mainly of sesquiterpenes i.e., $\delta$-cadinene $(12.1 \%)$ and $\beta$ caryophyllene (10\%)as reported by (Pinoet al., 2005). Satyal et al.,(2012) reported that, the essential oil isolated from Nepalsources mainly contain slimonene (64.1\%).The qualitative and quantitative variations between our results and the previous reports for the constituents of the leaves oil may be attributed to the difference in geographical location, climate conditions and time of harvest. Which comes in accordance with Verma et al., (2014) who reported that the growing location and time of harvest (season) had a close relation to the yield and quality of $A$. marmelos essential oil.

The essential oil isolated from A. marmelos (L.)Correa at dilution $1: 50(\mathrm{v} / \mathrm{v})$ showed antibacterial activity against all tested microorganisms; except for $K$. pneumoniae no activity was detected. A significant activity of the essential oil was observed against $S$. faecalis with inhibition zone $(30 \mathrm{~mm})$ and $P$. aeruginosa $(28 \mathrm{~mm})$. However, the oil revealed a moderate activity against $B$. subtilis $(23 \mathrm{~mm}), S$. aureus $(23 \mathrm{~mm})$, S. lutea $(20 \mathrm{~mm})$, A. citreus $(20 \mathrm{~mm})$ and $E$. coli $(25 \mathrm{~mm})$.A strong inhibitory effect against $A$. niger and C. albicans was recorded $(30 \mathrm{~mm})$ as compared with nystatin $(100 \mu \mathrm{g} / \mathrm{mL})$ (Table 2$)$.

The lowest minimal inhibitory concentration (MIC) value (Table 3) was against the most susceptible species of $A$. niger and C. albicans marked $50 \mu \mathrm{L} / \mathrm{mL}$, this was followed by E. coli and $B$. subtilis with $100 \mu \mathrm{L} / \mathrm{mL}$ and $150 \mu \mathrm{L} / \mathrm{mL}$ respectively. These values suggested that the essential oil possessed bacteriostatic and bactericidal activities and demonstrated great potential as an antifungal compound with potent in-vitro fungicidal activity against $C$. albicans, an opportunistic pathogen responsible for both superficial and systemic mycoses. Furthermore, the essentiall oil of A. marmelos (L.)Correa leaves (Table 4) demonstrated a significant inhibition of A. niger at concentration $(4,2,1 \% \mathrm{v} / \mathrm{v})$ and $F$. oxysporum spores at concentrations $(4,2 \% \mathrm{v} / \mathrm{v})$ with no response at concentration $1 \%(\mathrm{v} / \mathrm{v})$.Previous studies reported the antifungal activity of essential oil isolated from the leaves of Aegle marmelos (L.) Correa, with inhibition of the growth of dermatophytes and Fusarium species at concentration of 500 $\mu \mathrm{g} / \mathrm{mL}$ (Rana et al., 1997).

Table 3: MICs of the essential oil of A. marmelos (L.) Correa leaves.

\begin{tabular}{lc}
\hline Test organism & MIC $(\boldsymbol{\mu L} / \mathbf{m L})$ \\
\hline B. subtilis & 150 \\
E. coli & 100 \\
A. niger & 50 \\
C. albicans & 50 \\
\hline
\end{tabular}

Table.4:Effect of essential oil from A. marmelos (L.)Correa leaves on spore germination of $A$. niger and F. oxysporum.

\begin{tabular}{lcc}
\hline Conc. of oil mL \% & Aspergillus niger & Fusarium oxysporum \\
\hline $4 \%$ & $-\mathrm{ve}$ & $-\mathrm{ve}$ \\
$2 \%$ & $-\mathrm{ve}$ & $-\mathrm{ve}$ \\
$1 \%$ & $-\mathrm{ve}$ & $+\mathrm{ve}$ \\
\hline
\end{tabular}

Our obtained results for the antifungal activity of the oil come in accordance with Balakumar et al., (2011) who reported that the essential oil of A. marmelos (L.) Correa leaves have potent antifungal activity against the clinical isolates of dermatophytes. The mode of action of the essential oil as antimicrobial agents may be due to inhibition of respiration and disrupting the permeability barriers of the cell membrane structures (Cox etal.,2000).Furthermore, İşcan et al., (2012) reported that $\alpha$ phellandrene is the responsible for the antimicrobial activity, while the antibacterial and fungicidal activities Wedelia prostrata was mainly attributed to $\alpha$-pinene.

\section{CONCLUSION}

The biological activity of the essential oil isolated from the leaves of Aegle marmelos (L.)Correa was due to the synergism between the total components of the oil and mainly attributed to the presence of $\alpha$-phellandrene and $\alpha$-pinene as major constituents. The broad spectrum antimicrobial and antifungal activities of the 
oils against variety of pathogenic fungi and bacteria, can recommend its incorporation in different pharmaceutical preparations.

\section{REFERENCES}

Adams R.P. 2001. Identification of essential oils by Gas Chromatography Quadrupole Mass Spectrometry, Allured Publishing Corporation, Carol Stream, Illinois, USA.

Balakumar S., Rajan S., Thirunalasundari T. and Jeeva S. Antifungal activity of Aegle marmelos (L.) Correa (Rutaceae) leaf extract on dermatophytes. J. Trop. Med. 2011;1, 309-312.

Bansal Y.,Bansal G. Analytical methods for standardization of Aegle marmelos, A Review. J. Pharm. Educ. Res. 2011; 2, 37-44.

Bhatti R., Rawal S., Singh J., Ishar M.P.S. Effect of Aegle marmelos extract treatment on diabetic neuropathy in rats: a possible involvement of adrenoceptors. Int. J. Pharm. Pharmaceut. Sci. 2012; 4, 0975-1491.

Carson C.F., Cookson B.D., Riley T.V. Susceptibility of methicillin resistant Staphylococcus aureus to the essential oils of Melaleuca alternifolia. J. Antimicr. Chemother. 1995; 35, 421-424.

Chockalingam V., Kadali S., Gnanasambantham P. Antiproliferative and antioxidant activity of Aegle marmelos (Linn.) leaves in Dalton's Lymphoma Ascites transplanted mice.Int. J. Pharmacol. 2012; 44, 225-229.

Cox S.D., Mann C.M., Markham J.L. The mode of antimicrobial action of the essential oil of Melaleuca alternifolia (tea tree oil). J. Appl. Microbial. 2000; 88, 170-175.

Dhankhar S., Ruhil S., Balhara M., Dhankhar S., Chhillar A.K. Aegle marmelos (Linn.) Correa: A potential source of phytomedicine. J. Med. Plants Res. 2011; 5, 1497-1507.

Dai J., Zhu L., Yang L. and QiuJ. chemical composition, antioxidant and antimicrobial activities of essential oil from Wedelia prostrata. EXCLI J. 2013; 12:479-490.

Egyptian Pharmacopoeia, the English Text of Arab Republic of Egypt, Ministry of Health and Population, $4^{\text {th }}$ edition, Central Administration and Pharmaceutical Affairs Ministry of Health and population. 2005; pp. 1295, Cairo, Egypt,

Elgayyar M., Draughon F.A., Golden D.A., Mount J.R. Antimicrobial activity of essential oils from plants against selected pathogenic and saprophytic microorganisms. J. Food Protect. 2001; 64, 1019-1024.

İşcan G., Kirimer N., Demirci F., Demirci B., Noma Y., Başer K.H. Biotransformation of (-)-(R)- $\alpha$-phellandrene: antimicrobial activity of its major metabolite. J. Chem. Biodiversity, 2012; 9,1525-1532.

Linday E.M. (1962). Practical introduction to microbiology. (E. and FN spon Ltd), UK.
Kothari S., Mishra V., Bharat S., Tonpay S.D. Antimicrobial activity and phytochemical screening of serial extracts from leaves of Aegle marmelos (Linn.) Acta Polonica Pharmaceut. Drug Res. 2011; 68, 687-692.

Pino J.A., Marbot R., Fuentes V. Volatile compounds from leaves of Aegle marmelos (L.) Correa grown in Cuba. Revista CENIC. Ciencias Químicas, 2005; 36, 71-73.

Plascencia-Jatomea M., Viniegra G., Olaya, R., Castillo-Ortega M.M., Shirai K. Effect of chitosan and temperature on spore germination of Aspergillus niger. Macromol. Biosci.2003; 3, 582-586.

Rahman S., Parvin R. Therapeutic potential of Aegle marmelos (L.) -An overview. Asian Pacific J. Tropical Dis. 2014; 4, 71-77.

Raju P.M., Agarwal S.S., Ali M., Velasco-Negueruela A., Pérez-Alonso M.J. Chemical Composition of the leaf oil of Aegle marmelos (L.) Correa. J. Essen. Oil Res. 1999;11, 311-313.

Rana B.K., Singh U.P., Taneja V. Antifungal activity and kinetics of inhibition by essential oil isolated from Aegle marmelos. J. Ethnopharmacol. 1997; 57, 29-34.

Satyal P., Woods K.E., Dosoky N.S., Neupane S., Setzer W.N. Essential oil constituents and biological activity of Aegle marmelos (L.) Corr. Serr. From Nepal. J. Med. Active Plants. 2012; 1, 114-122.

Sekar D.K., Kumar G., Karthik L., Rao K.V.B. A review on pharmacological and phytochemical properties of Aegle marmelos (L.) Corr. Serr. (Rutaceae) Asian J. Plant Sci. Res. 2011; 1, 8-17.

Shenoy A.M., Singh R., Samuel R.M., Yedle R., Shabraya A.R.Evaluation of antiulcer activity of Aegle marmelos leaves extract. Int J. Pharmaceut. Sci. Res.2012; 3, 1498-1500.

Venkatesan D., Karrunakarn C.M., Kumar S.S., Swamy P.T.P. Identification of phytochemical constituents of Aegle marmelos responsible for antimicrobial activity against selected pathogenic organisms. Ethnobotanical Leaflets. 2009; 13,1362-1372.

Verma R.S., Padalia R.C., Chauhan A. Essential oil composition of Aegle marmelos (L.) Correa: chemotypic and seasonal variations. J. Sci. Food Agric. 2014; 94, 1904-1913.

\section{How to cite this article:}

Nabaweya A. Ibrahim, Fatma S. El-Sakhawy, Magdy M. D. Mohammed, Mohamed A. Farid, Nayera A. M. Abdel-Wahed, Doaa A.-H. Deabes. Chemical Composition, Antimicrobial and AntifungalActivities of the Essential Oil ofthe Leaves of Aegle marmelos (L.)Correa Growingin Egypt. J App Pharm Sci, 2015; 5 (02): 001-005. 